УДК 632.4:57.03

\title{
ДЕРЕВОРАЗРУШАЮЩИЕ СВОЙСТВА АРКТИЧЕСКИХ ШТАММОВ PORODAEDALEA NIEMELAEI M. FISCHER И TRICHODERMA ATROVIRIDE BISSETT
}

\author{
() Ю.А. Литовка ${ }^{1,2 *}$, И.Н. Павлов ${ }^{2}$, Т.В. Рязанова ${ }^{1}$, Е.А. Литвинова ${ }^{1}$, Н.А. Чупрова ${ }^{I}$ \\ ${ }^{1}$ Сибирский государственный аэрокосмический университет им. академика \\ М.Ф. Решетнева, пр. Мира, 82, Красноярск, 660049 (Россия), \\ e-mail: litovkajul@rambler.ru \\ ${ }^{2}$ Институт леса им. В.Н. Сукачева СО РАН, Академгородок, 50/28, \\ Красноярск, 660036 (Россия)
}

\begin{abstract}
Представлены результаты исследования дереворазрушающих свойств макроскопического гриба Porodaedalea niemelaei M. Fischer и микромицета Trichoderma atroviride Bissett, выделенных в чистую культуру соответственно из плодового тела и древесины Larix gmelinii (Rupr.) Rupr., обнаруженных в высоких широтах на северном пределе произрастания древесных растений. Изучена динамика фенолоксидазной активности штаммов и биоконверсия растительных отходов лесопереработки при их твердофазной ферментации. Исследуемые грибы в лабораторных условиях колонизируют лиственные и хвойные субстраты в моно- и совместной культуре; степень биодеструкции зависит от ферментативной активности культуры и химических особенностей ростового субстрата. Максимальная дереворазрушающая активность отмечена у штамма PnB-13 Porodaedalea niemelaei на опилках осины. Убыль массы составила 39\%; по сравнению с исходным субстратом сумма полисахаридов уменьшилась в 1,6 раза; содержание легкогидролизуемых полисахаридов сократилось в 1,8 раза; трудногидролизуемых полисахаридов - в 1,5 раза; веществ лигниновой природы - в 1,2 раза; концентрация водорастворимых веществ увеличилась в 1,5 раза. Виды $P$. niemelaei и T. atroviride продуцируют экстрацеллюлярные оксидазы лигнолитического комплекса при твердофазном культивировании на растительных отходах; активность фенолоксидазы находится в диапазоне 0,15-0,22 ед/г·с на опилках лиственницы и 0,14-0,18 ед/г·с на опилках осины, что сопоставимо с ферментативной активностью других ксилотрофных базидиомицетов (Trametes versicolor, Armillaria mellea s.l., Heterobasidion parviporum).

Ключевые слова: Porodaedalea niemelaei, Trichoderma atroviride, биодеструкция, растительные субстраты, твердофазное культивирование, лигно-углеводный комплекс, полифенолоксидазная активность.
\end{abstract}

Работа выполнена при финансовой поддержке РФФИ и Правительства Красноярского края в рамках научного проекта № 16-44-242145 p_oфи_м.

Литовка Юлия Александровна - кандидат биологических наук, доцент кафедры химической технологии древесины и биотехнологии, e-mail: litovkajul@rambler.ru

Павлов Игорь Николаевич - доктор биологических наук, профессор, заведующий лабораторией лесных культур, микологии и фитопатологии, заместитель директора по научной работе, e-mail: litovkajul@ rambler.ru Рязанова Татьяна Васильевна - доктор технических наук, профессор, заведующий кафедрой химической технологии древесины и биотехнологии, e-mail: litovkajul@rambler.ru

Литвинова Екатерина Алексеевна - аспират, e-mail: litovkajul@rambler.ru

Чупрова Нелли Александровна - кандидат технических наук, доцент кафедры химической технологии древесины и биотехнологии,

e-mail: litovkajul@rambler.ru

\section{Введение}

Ксилотрофные базидиомицеты - это относительно небольшая по числу видов экологическая группа грибов, которая играет ведущую роль в системе редуцентов, обеспечивая круговорот веществ и перераспределение энергии в лесных экосистемах за счет биоконверсии лигноцеллюлозного комплекса древесины. Биодеградация природных полимеров осуществляется различными путями, при этом ведущим механизмом является действие сложного мультиферментного комплекса, синтез которого зависит от ростового субстрата, физиологобиохимических и генетических особенностей штамма. Ферментативная деградация осуществляется

\footnotetext{
* Автор, с которым следует вести переписку.
} 
преимущественно с участием оксидоредуктаз и гидролаз, что предопределяет значимость этих ферментов в процессах биоразрушения трудногидролизуемых полимеров. В настоящее время ведется интенсивная разработка технологий на основе лигнолитических грибов и их ферментов для обработки лигноцеллюлозных материалов и утилизации растительных отходов [1-3].

Грибы рода Porodaedalea, вызывая биомодификацию древесины, являются одними из наиболее важных фитопатогенов - возбудителей стволовой гнили хвойных деревьев в северном полушарии, особенно в старовозрастных насаждениях сосны обыкновенной [4-6]. Вид Porodaedalea niemelaei - это один из немногих дереворазрушающих грибов, произрастающих в районах вечной мерзлоты на северном пределе произрастания древесных растений, что обусловливает наличие у него уникальных ферментных систем, обеспечивающих жизнеспособность и дереворазрушающую активность при относительно низких температурах [7]. Психрофильные свойства наряду с мультиферментным комплексом, деградирующим лигноцеллюлозные материалы, позволяют рассматривать представителей этого вида как потенциальных продуцентов ферментов для эффективной биодеградации растительных отходов. В связи с этим целью данного исследования являлась оценка способности штамма PnB-13 Porodaedalea niemelaei, а также сопутствующего ему штамма PnD-13 Trichoderma atroviride продуцировать внеклеточные оксидазы лигнолитического комплекса в ходе биодеструкции древесины Larix sibirica L. и Populus tremula L. в условиях твердофазного культивирования.

\section{Экспериментальная часть}

Основным объектом исследования служил штамм PnB-13 базидиального гриба, выделенный из плодового тела Porodaedalea niemelaei в 2013 году. Плодовое тело было обнаружено на ветровальном дереве Larix gmelinii (Rupr.) Kuzen. в лиственничном редколесье в нижнем течении р. Хета (Таймыр) (N 71 41,97' E $100^{\circ}$ 34,54'). Одновременно из древесины Larix gmelinii, пораженной P. niemelaei, в чистую культуру был изолирован сопутствующий штамм PnD-13 микроскопического гриба Trichoderma atroviride. Выделение чистых культур осуществляли методом накопления во влажной камере с последующим пересевом на твердую питательную среду [8]. Видовая принадлежность установлена с помощью метода ПЦР с ITS-праймерами. Полученные последовательности представлены в Genbank (инвентарные номера KU687403 и KU687404).

Наличие общей фенолоксидазной активности оценивали на сусловой среде с добавлением 0,5\% танина [8]. Твердофазное культивирование осуществляли на опилках Larix sibirica L. и Populus tremula L. при влажности субстрата $70 \%$ и температуре $20 \pm 1{ }^{\circ} \mathrm{C}$ в течение 25 суток. Исходным объектом для последующих исследований служили растительные субстраты, высушенные до воздушно-сухого состояния и проходящие через сито с отверстием 3 мм. Для определения биохимических характеристик субстрата до и после культивирования использовали методы, принятые в химии древесины [9]. Активность полифенолоксидазы определяли фотоколориметрически по скорости развития окраски в окислительновосстановительных реакциях, сопряженных с окислением фенолов, используя систему пирокатехин- $p$ фенилендиамин [10]. Микопаразитическую активность Trichoderma atroviride в отношении Porodaedalea niemelaei исследовали методом мицелиальных пленок по трехбалльной шкале [11].

\section{Обсуждение результатов}

Штамм РnB-13, изолированный из плодового тела, на натуральных питательных средах обладает макро- и микроморфологическими особенностями, характерными для вида Porodaedalea niemelaei (воздушный мицелий пушистый с порошистым налетом; цвет белый, затем желтый, охряный до темнокоричневого с выраженными концентрическими зонами; реверс темно-коричневый; запах слабый грибной). Культивирование штамма на питательных средах различного состава позволило установить, что наиболее благоприятными для его хранения и получения инокулюма в лабораторных условиях являются среды на основе натуральных компонентов (сусло-агар, морковный агар, сусло-агар с отваром дубовой коры, картофельно-глюкозный агар и овсяный агар). Максимальная скорость роста на этих средах отмечена на 17-е сутки культивирования; ее значения находились в диапазоне 0,7-1,5 мм/сут. При смене натуральной среды на синтетическую отмечено изменение морфологии, включая высоту мицелия, плотность колонии и ее структуру, пигментацию субстратного и воздушного мицелия, что свидетельствует о различной адаптации штамма к составу ростового субстрата. Из сред на основе синтетических компонентов наиболее пригодными для культивирования являются КНО-агар, агар Модесса и агар Возняковой, радиальная скорость роста на которых составила в среднем 1 мм/сут. 
Исследуемая культура характеризуется максимальной радиальной скоростью роста при температуре 18-20 ${ }^{\circ} \mathrm{C}$, что, по-видимому, обусловлено особенностью климатических условий естественного местообитания гриба; при 4 и $28{ }^{\circ} \mathrm{C}$ рост останавливается. Таким образом, поддержание штамма PnB-13 P. niemelaei в лабораторных условиях и его культивирование на растительных субстратах и питательных средах целесообразнее осуществлять при температуре $20{ }^{\circ} \mathrm{C}$.

Для оценки способности грибов биодеструктировать лигно-углеводный комплекс осуществляли их твердофазное культивирование в моно- и совместной культуре на опилках Larix sibirica и Populus tremula с последующим определением биохимических характеристик субстрата до и после культивирования. Результаты определения химического состава исходного сырья показали, что исследуемые субстраты представляют собой сложный химический комплекс веществ, существенно различающийся по составу в зависимости от древесной породы. В древесине лиственницы содержание водорастворимых веществ в 3,1 раза выше, чем в древесине осины. Химический состав исходных субстратов представлен более чем на $60 \%$ полисахаридами, при этом доля трудногидролизуемых полисахаридов практически не различается и составляет 45-46\% от массы а.с.с., а количество легкогидролизуемых полисахаридов в 1,6 раз больше в опилках осины по сравнению с лиственничным субстратом. В целом, на долю лигноуглеводного комплекса приходится $86 \%$ от массы а.с.с для опилок лиственницы и 91\% - для опилок осины, что свидетельствует о возможности проведения их глубокой биоконверсии (табл. 1, 2).

Твердофазное культивирование грибов на растительных субстратах показало, что исследуемые штаммы активно колонизируют древесные опилки в моно- и совместной культуре, при этом степень биодеструкции зависит от ферментативной активности культуры и биохимических особенностей ростового субстрата. Максимальная дереворазрушающая активность отмечена у штамма PnB-13 P. niemelaei на опилки осины. Убыль массы субстрата составила 39\%; сумма полисахаридов уменьшилась в 1,6 раза в сравнении с исходным субстратом; содержание легкогидролизуемых полисахаридов сократилось в 1,8 раза; трудногидролизуемых полисахаридов - в 1,5 раза; веществ лигниновой природы - в 1,2 раза. Отмечено увеличение концентрации водорастворимых веществ относительно исходного субстрата в 1,5 раза (табл. 1). При культивировании штамма PnD-13 T. atroviride на опилках осины отмечена аналогичная тенденция использования преимущественно веществ углеводного комплекса. Содержание веществ лигниновой природы осталось практически неизменным, убыль массы субстрата составила 15\%. Дереворазрушающая активность при совместном культивировании макро- и микроскопического грибов оказалась выше, чем в монокультуре PnD-13 T. atroviride, но уступала штамму PnB-13 P. niemelaei, что свидетельствует о наличии между ними конкурентных взаимоотношений, изученных далее.

Таблица 1. Химический состав древесины осины до и после биодеструкции

\begin{tabular}{l|c|c|c|c}
\hline \multirow{2}{*}{\multicolumn{1}{c|}{ Наименование показателя }} & \multicolumn{3}{|c}{ Содержание, \% от а.с.с. с учетом убыли массы образца } \\
\cline { 2 - 5 } & $\begin{array}{c}\text { исходный } \\
\text { субстрат }\end{array}$ & $\begin{array}{c}\text { Porodaedalea } \\
\text { niemelae }\end{array}$ & $\begin{array}{c}\text { Trichoderma } \\
\text { atroviride }\end{array}$ & $\begin{array}{c}\text { Porodaedalea }+ \\
\text { Trichoderma }\end{array}$ \\
\hline Водорастворимые вещества & 2,8 & 4,3 & 4,4 & 2,8 \\
Легкогидролизуемые полисахариды & 23,3 & 12,9 & 16,9 & 13,7 \\
Трудногидролизуемые полисахариды & 45,1 & 30,7 & 38,6 & 34,2 \\
Сумма полисахаридов & 68,4 & 43,6 & 55,5 & 47,8 \\
Негидролизуемый остаток & 23,8 & 20,2 & 23,7 & 20,4 \\
Убыль массы & - & 38,9 & 14,9 & 28,9 \\
Лигноуглеводный комплекс & 92,2 & 64,8 & 79,2 & 68,2 \\
\hline
\end{tabular}

Таблица 2. Химический состав древесины лиственницы до и после биодеструкции

\begin{tabular}{|c|c|c|c|c|}
\hline \multirow[b]{2}{*}{ Наименование показателя } & \multicolumn{4}{|c|}{ Содержание, \% от а.с.с. с учетом убыли массы образца } \\
\hline & $\begin{array}{c}\text { исходный } \\
\text { субстрат }\end{array}$ & $\begin{array}{c}\text { Porodaedalea } \\
\text { niemelaei }\end{array}$ & $\begin{array}{c}\text { Trichoderma } \\
\text { atroviride }\end{array}$ & $\begin{array}{c}\text { Porodaedalea }+ \\
\text { Trichoderma }\end{array}$ \\
\hline Водорастворимые вещества & 8,7 & 6,6 & 5,3 & 3,5 \\
\hline Легкогидролизуемые полисахариды & 15,0 & 12,2 & 13,5 & 13,3 \\
\hline Трудногидролизуемые полисахариды & 46,0 & 33,8 & 30,9 & 37,7 \\
\hline Сумма полисахаридов & 61,0 & 45,7 & 44,4 & 51,0 \\
\hline Негидролизуемый остаток & 24,6 & 22,7 & 21,8 & 24,1 \\
\hline Убыль массы & - & 25,0 & 28,2 & 18,6 \\
\hline Лигноуглеводный комплекс & 85,6 & 68,7 & 66,2 & 75,0 \\
\hline
\end{tabular}


В процессе ферментации лиственничных опилок отмечены общие закономерности биохимических изменений субстрата в монокультуре обоих штаммов (табл. 2). Убыль массы составила 25-28\% на фоне уменьшения количества всех исследуемых показателей по сравнению с исходными значениями. Содержание водорастворимых веществ сократилось в 1,3-1,6 раза; сумма полисахаридов уменьшилась в среднем в 1,3 раза; содержание легко-, трудногидролизуемых полисахаридов и веществ лигниновой природы - соответственно в 1,2; 1,4 раза и 1,1 раза. В совместной культуре на опилках лиственницы отмечена минимальная убыль массы субстрата при использовании преимущественно водорастворимых веществ и, в меньшей степени, полисахаридного комплекса при неизменных показателях содержания веществ лигниновой природы.

Таким образом, в ходе проведенного исследования установлено, что максимальной дереворазрушающей активностью обладает штамм PnB-13 базидиального гриба P. niemelaei, который способен биодеструктировать опилки хвойных и лиственных пород, отдавая предпочтение веществам углеводного комплекса. Процессы биоконверсии эффективнее протекают на опилках осины, по-видимому, из-за более высокого содержания в них легкогидролизуемых полисахаридов.

Изучение фенолоксидазной активности показало, что исследуемые культуры грибов продуцирует экстрацеллюлярные оксидазы лигнолитического комплекса: на сусловой среде с танином отмечено появление пигментированной зоны темно-коричневого цвета даже при минимальной скорости роста (у штамма PnB-13) и отсутствии хорошо развитого мицелия. Диаметр пигментированной зоны значительно превышает размер колонии, что позволило отнести оба штамма к первой группе по Бавендамму и рассматривать их как потенциальных продуцентов лигнолитических ферментов.

Количественное определение фенолоксидазы позволило установить, что штамм PnB-13 в монокультуре проявляет ферментативную активность начиная с 14-х суток твердофазного культивирования на растительных субстратах, значения которой находились в диапазоне 0,15-0,22 ед/г·с на опилках лиственницы и 0,14-0,18 - на опилках осины. Динамика активности была волнообразной с максимумом на 14 и 42 -е сутки культивирования на хвойном субстрате, а также на 21 и 42-е сутки культивирования - на лиственном субстрате (рис.).

Активность штамма PnD-13 T.atroviride на опилках лиственницы находилась в пределах 0,14-0,21 с максимумом на 14 и 42-е сутки культивирования; на опилках сосны - в диапазоне 0,15-0,19 ед/гc с максимумом на 14-е сутки и достоверно не отличалась от P.niemelaei. При совместном культивировании динамика активности и количественные показатели были чуть ниже, но в целом сопоставимы со значениями в монокультуре: на опилках лиственницы 0,13-0,18 ед/г·c; на опилках сосны 0,12-0,19 ед/г·c.

Для сравнительной оценки полифенолоксидазной активности Porodaedalea niemelaei с другими базидиальными ксилотрофами, провели оценку их ферментативной активности на аналогичных субстратах (табл. 3). Установлено, что активность полифенолоксидазы базидиомицетов находится в диапазоне 0,190,23 ед/г·c - на опилках осины и 0,18-0,27 ед/г·c - на опилках лиственницы; максимальной ферментативной активностью характеризуются Trametes versicolor и Armillaria mellea s.l. Полифенолоксидазная активность P.niemelaei при меньших, в большинстве случаев, показателях радиальной скорости роста на растительных субстратах сопоставима со значениями изученных культур базидиальных грибов, а на 21-е сутки культивирования в ряде случаев превышает этот показатель.

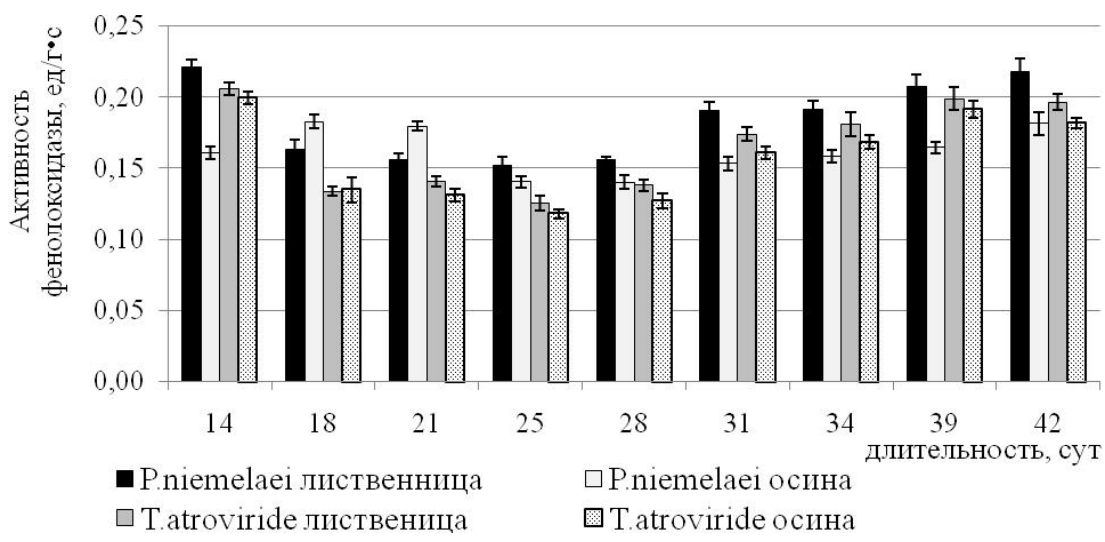

Фенолоксидазная активность Porodaedalea niemelaei и Trichoderma atroviride при твердофазном культивировании на растительных субстратах 
Таблица 3. Активность фенолоксидазы (ед/г·c) и радиальная скорость роста (мм/сут) при культивировании грибов на растительных субстратах

\begin{tabular}{l|c|c|c}
\hline \multirow{2}{*}{ Вид } & Длительность культивирования, сут & \multirow{2}{*}{ Радиальная скорость роста } \\
\cline { 2 - 3 } & 14 & 21 & $0,9 / 0,9$ \\
при $20{ }^{\circ}$ С** & $0,21 / 0,22$ & $1,3 / 1,2$ \\
Porodaedalea niemelaei & $0,19 / 0,18^{*}$ & $0,20 / 0,18$ & $2,1 / 1,9$ \\
Trametes versicolor & $0,21 / 0,20$ & $0,24 / 0,22$ & $0,2 / 0,3$ \\
Armillaria mellea s.l. & $0,20 / 0,19$ & $0,19 / 0,27$ & \\
\hline
\end{tabular}

Примечания. * в числителе - опилки осины; в знаменателе - опилки лиственницы; ** на 14-е сутки культивирования; *** рост отсутствовал

В исследованиях по совместному культивированию макро- и микромицета на растительных субстратах выявлено менее эффективное протекание процессов биодеструкции по сравнению с монокультурой, что, вероятно, связано, с конкуренцией за ростовой субстрат. Грибы рода Trichoderma широко известны своими микопаразитическими свойствами, что было подтверждено нашими исследованиями. Изучение микопаразитической активности проводили на мицелиальной пленке базидиального гриба, на которую была нанесена суспензия T. atroviride с титром $1 \times 106$ кое/мл. На седьмые сутки обрастание пленки мицелием T. atroviride составило 30\% (степень микопаразитизма - 1 балл); на 14-е сутки отмечено появление очагового спороношения и обрастание $60 \%$ пленки (2 балла); на 21-е сутки - массовое спороношение и обрастание $100 \%$ площади пленки (3 балла). Таким образом, конкуренция за ростовой субстрат, высокая скорость роста и выраженные микопаразитические свойства T. atroviride являются основными причинами замедления биодеструкции растительных субстратов при совместном культивировании штаммов in vitro. Одновременное присутствие в древесине фитопатогенного гриба P.niemelaei и его микопаразита T. atroviride следует рассматривать, как один из защитных механизмов, сдерживающих развития фитопатогена в природных условиях.

\section{Заключение}

Арктические штаммы грибов Porodaedalea niemelaei и Trichoderma atroviride колонизируют растительные субстраты, в различной степени изменяя биохимический состав исходного сырья. Оба штамма в монокультуре более эффективно биодеструктируют лиственничные опилки по сравнению с совместным культивированием, отдавая предпочтение веществам углеводного комплекса. Опилки осины в большей степени подвержены биодеструкции Porodaedalea niemelaei - убыль массы субстрата составила 39\%; содержание полисахаридов уменьшилось в 1,6 раза; лигниновых веществ - в 1,2 раза. Porodaedalea niemelaei и Trichoderma atroviride продуцируют экстрацеллюлярные оксидазы лигнолитического комплекса при твердофазном культивировании на растительных субстратах. Штамм PnB P. niemelaei в монокультуре проявляет максимальную фенолоксидазную активность, начиная с 14-х суток твердофазного культивирования, значения которой находится в диапазоне 0,15-0,22 ед/г`с на опилках лиственницы и 0,14-0,18 - на опилках осины, что сопоставимо с ферментативной активностью других базидиальных грибов.

Штамм PnD-13 Trichoderma atroviride проявляют высокую микопаразитическую активность в отношении Porodaedalea niemelaei, что является одной из причин замедления процессов биодеструкции растительных субстратов и ферментативной активности в лабораторных условиях при их совместном культивировании.

\section{Список литературы}

1. Фёдорова Т.В., Шахова Н.В., Кляйн О.И., Глазунова О.А., Малошенок Л.Г., Куликова Н.А., Псурцева Н.В., Королёва О.В. Сравнительный анализ лигнолитического потенциала базидиальных грибов, принадлежащих к различным таксономическим и экологическим группам // Прикладная биохимия и микробиология. 2013. T. 49. №6. С. 570-579.

2. Бондарцева М.А. Эколого-биологические закономерности функционирования ксилотрофных базидиомицетов в лесных экосистемах // Грибные сообщества лесных экосистем: материалы координац. исслед. М.Петрозаводск, 2000. С. 9-25.

3. Сафонов М.А., Маленкова А.С. Микобиота лесополос степной зоны Южного Урала (Оренбургская область) // Успехи современного естествознания. 2014. №2. С. 40-45.

4. Brazeel N.J., Lindner D.L. Unraveling the Phellinus pini s.l. complex in North America: a multilocus phylogeny and differentiation analysis of Porodaedalea // Forest Pathology. 2013. Vol. 43. Pp. 132-143.

5. Ежов О.Н., Конюшатов О.А. Распределение гнили сосновой губки в стволах сосен // Лесоведение. 2001 . №1. C. 71-74.

6. Павлов И.Н. Дереворазрушающие и патогенные свойства Porodaedalea niemelaei M. Fischer в редколесьях Larix gmelinii на северном пределе произрастания // Вредители и болезни древесных растений России: материалы международной конференции. СПб., 2013. С. 69-70. 
7. Farrell R.L., Arenz B.E., Duncan S.M., Held B.W., Jurgens J.A., Blanchette R.A. Introduced and indigenous fungi of the Ross Island historic huts and pristine areas of Antarctica // Polar Biology. 2011. Vol. 34(11). Pp. 1669-1677.

8. Методы экспериментальной микологии / под ред. В.И. Билай. Киев, 1982. 550 c.

9. Riazanova T.V., Chuprova N.A., Isaeva E.V. Wood Chemistry. LAP LAMBERT Academic Publishing, 2012. 428 p.

10. Бояркин А.Н. Быстрый метод определения активности полифенолоксидазы (модифицированный) // Труды Института физиологии растений АН СССР. 1954. Т. 8, вып. 2. С. 398-403.

11. Егоров Н.С. Основы учения об антибиотиках. М., 1994. 512 с.

Поступило в редакиию 14 ноября 2016 г. После переработки 20 января 2017 г.

\footnotetext{
Litovka Y.A. ${ }^{1,2}$, Pavlov I.N. ${ }^{2}$, Ryazanova T.V. ${ }^{l}$, Litvinova E.A. ${ }^{l}$, Chuprova N.A. ${ }^{l}$ WOOD-DESTROYING PROPERTIES OF PORODAEDALEA NIEMELA M. FISCHER AND TRICHODERMA ATROVIRIDE BISSETT FROM PERMAFROST AREA

${ }^{1}$ Siberian State Aerospace University. Academician M.F. Reshetnev, pr. Mira, 82, Krasnoyarsk, 660049 (Russia),

e-mail: litovkajul@rambler.ru

${ }^{2}$ Institute of Forest. V.N. Sukachev, Siberian Branch of the Russian Academy of Sciences, Akademgorodok, 50/28,

Krasnoyarsk, 660036 (Russia)
}

Presents the results of a research of wood-destroying properties Porodaedalea niemelaei M. Fischer and Trichoderma atroviride Bissett. The strains were isolated in pure culture from the fruiting body and larch wood (Larix gmelinii (Rupr.) Rupr.) in permafrost. Studied phenol oxidase activity and biodegradation of waste wood at their solid-state fermentation. Under laboratory conditions, fungi colonize deciduous and coniferous substrates in monoculture and co-culture. Bioconversion depends on the enzymatic activity of strains and chemical characteristics of the growth substrate. Maximum of wooddestroying activity observed in strain PnB-13 Porodaedalea niemelaei on sawdust of aspen. The loss of weight of the substrate was $39 \%$; polysaccharide content decreased to 1,6 times in comparison with the initial substrate; lignin - in 1.2 times. The concentration of water-soluble substances increased 1,5 times. $P$. niemelaei and $T$. atroviride produce extracellular oxidase of lignolytic complex in the solid-phase cultivation of plant residues. Enzyme activity was $0,15-0,22 \mathrm{u} / \mathrm{g} \cdot \mathrm{s}$ on sawdust of larch and $0,14-0,18 \mathrm{u} / \mathrm{g} \cdot \mathrm{s}$ on sawdust of aspen, which is comparable to the phenol oxidase activity of other xylotrophic basidiomycetes (Trametes versicolor, Armillaria mellea s.l., Heterobasidion parviporum).

Keywords: Porodaedalea niemelaei, Trichoderma atroviride, biodegradation, waste wood, solid-state cultivation, lignocarbohydrate complex, phenol oxidase activity.

\section{References}

1. Fedorova T.V., Shakhova N.V., Kliain O.I., Glazunova O.A., Maloshenok L.G., Kulikova N.A., Psurtseva N.V., Koroleva O.V. Prikladnaia biokhimiia i mikrobiologiia, 2013, vol. 49, no. 6, pp. 570-579. (in Russ.).

2. Bondartseva M.A. Gribnye soobshchestva lesnykh ekosistem: materialy koordinats. issled. [Fungal community forest ecosystems: materials research coordination]. M.-Petrozavodsk, 2000, pp. 9-25. (in Russ.).

3. Safonov M.A., Malenkova A.S. Uspekhi sovremennogo estestvoznaniia, 2014, no. 2, pp. 40-45. (in Russ.).

4. Brazeel N.J., Lindner D.L. Forest Pathology, 2013, vol. 43, pp. 132-143.

5. Ezhov O.N., Koniushatov O.A. Lesovedenie, 2001, no. 1, pp. 71-74. (in Russ.).

6. Pavlov I.N. Vrediteli i bolezni drevesnykh rastenii Rossii: materialy mezhdunarodnoi konferentsii. [Pests and diseases of woody plants Russia: Proceedings of the International Conference]. St. Petersburg, 2013, pp. 69-70. (in Russ.).

7. Farrell R.L., Arenz B.E., Duncan S.M., Held B.W., Jurgens J.A., Blanchette R.A. Polar Biology, 2011, vol. 34(11), pp. 1669-1677.

8. Metody eksperimental'noi mikologii. [Methods of Experimental Mycology], ed. V.I. Bilai, Kiev, 1982, 550 p. (in Russ.).

9. Riazanova T.V., Chuprova N.A., Isaeva E.V. Wood Chemistry, LAP LAMBERT Academic Publishing, 2012, 428 p.

10. Boiarkin A.N. Trudy Instituta fiziologii rastenii AN SSSR, 1954, vol. 8, no. 2, pp. 398-403. (in Russ.).

11. Egorov N.S. Osnovy ucheniia ob antibiotikakh. [Fundamentals of theory of antibiotics]. Moscow, 1994, 512 p. (in Russ.).

\footnotetext{
* Corresponding author.
} 